\section{Non-integrated Universities and Long-standing Problems The Universities of Zagreb and Belgrade in the Socialist Federal Republic of Yugoslavia and Today}

\author{
Nikola BAKETA \\ Faculty of Political Science, University of Zagreb
}

\begin{abstract}
The higher education system of the Socialist Federal Republic of Yugoslavia displayed three specific characteristics - a) non-integrated universities, b) absence of a federal ministry of education since the 1970s, and b) self-managed Communities of Interest as the decision-maker in the higher education system. Therefore, there was no direct connection between the universities and economic planning. The author considers this to be one of the causes of high unemployment of graduates and brain drain towards Croatia and Serbia. Twenty years after the dissolution of the SFRY, the universities are still not integrated, there aren't any connections with the market, and the same problems prevail. This paper focuses on the flagship universities from Croatia and Serbia. The author uses the historical institutionalism framework, document analysis and the process tracing method in order to explain and connect these issues. As a conclusion, the author offers three solutions for the reorganization of non-integrated universities.
\end{abstract}

Keywords: higher education, university, Yugoslavia, unemployment, brain drain.

\section{Introduction}

In the Socialist Federal Republic of Yugoslavia (SFRY), higher education displayed three specific characteristics - a) non-integrated universities (with relatively autonomous faculties), b) the absence of a federal ministry of education since the 1970s, and c) self- managed Communities of Interest as the decision-maker in the HE. The result was the complete absence of any connection between the universities and economic planning, which, in turn, triggered high unemployment among graduates and brain drain. Twenty years after the dissolution of the SFRY, the heritage of that regime has

•e-mail: baketa.nikola@gmail.com. Nikola Baketa is a PhD student at the Faculty of Political Science in Zagreb. He enrolled in BA at Faculty of Political Science Zagreb in 2006. In 2010 he started the Master program in Political Science at Central European University in Budapest (specialized in Comparative politics) and Master program at Faculty of Political Science Zagreb (specialized in Public policy). He graduated at both universities (Theses titles: 'The European Union's conditionality mechanism and democratic consolidation in the post-communist EU candidate countries' and 'Europeanization of adult education - the case study of Croatia' ). Nikola has published in 'Političke analize', 'Mali levijatan' and 'Andragoški glasnik'. In March 2012, Nikola joined the NORGLOBAL research project 'European Integration in Higher Education and Research in the Western Balkans'. The research interests are in the following areas: public policy, higher education, europeanizaton. 
become visible. Universities are still not integrated, there are no established connections with the market, and the problems of unemployment among graduates and brain drain still remain. This paper focuses on flagship universities from Croatia and Serbia. The problem is approached from the historical institutionalism perspective. Document analysis and the analysis of previous research in this area are also used, since some documents are not available. Finally, the author uses the process tracing method in order to explain the position of non-integrated universities in regard to the prevailing economic system and the ensuing problems. The final part presents three solutions for the reorganization of nonintegrated universities in order to avoid long-term problems.

\section{Historical background}

The higher education institutions from Croatia and Serbia have a long history. The predecessors of the University of Zagreb and the University of Belgrade were established under the influence of Austria-Hungary and Turkey. The first higher education institution in Zagreb was established in 1669, and it was called Neoacademia Zagrabiensis. It was managed by the Jesuit order, and in 1776 Empress Maria Theresa decided that the state should take control over the education institutions, and so the Regia Scientiarum Academia replaced the previous institution. The next transformation occurred in 1850 , this was the result of the 1848 revolutionary events. Jurisprudence was included in the study program, and the institution was named the Academy of
Jurisprudence. Finally, the University of Zagreb was established in 1874, and it comprised three schools - Theology, Philosophy and Law (Samolovčev, 1989).

The University of Belgrade was also developed in several steps, too. In 1808 the Higher School was established and the role model for that institution was found in the Royal Academy institutions of higher learning in the Austro-Hungarian Monarchy. After the uprising and revolution in 1813 this institution was closed and its successor was Lyceum which was established in 1838. The next change happened in 1863 when Lyceum was replaced with the Higher School (Academy). This new institution had three Faculties Philosophy, Technical Sciences and Law. In the end, the University was established in 1905 and at that time it included five Faculties - Theology, Philosophy, Law, Medicine, Technical and Engineering Sciences. (Šoljan, 1991)

Samolovčev (1989:13) differentiates five periods in the development of higher education in Yugoslavia:

1. The period of isolated and differentiated higher education development;

2. The period of socially integrated higher education development under capitalist social conditions, 19181941;

3. The period of socialist socioideological and pedagogical higher education transformation, 1945-1954;

4. The period of self-managing higher education transformation and expansion, 1954-1982;

5 . The period of rational qualitative higher education development, 1982 to date $^{1}$. 
The first period includes the higher education development described above. The next period was characterized by the establishment of the Kingdom of the Serbs, Croats and Slovenes, and the leaders' efforts to integrate education (governing bodies at universities, changing the name of the University of Zagreb into the University of the Kingdom of the Serbs, Croats and Slovenes in Zagreb), enlarge the system (the setup of the University of Ljubljana, at the time called the University of the Kingdom of the Serbs, Croats and Slovenes in Ljubljana,) and change the internal organizations of these institutions. However, during this period, the higher education system did not achieve a significant development. Before World War II, in Yugoslavia there were only three universities, with 18 faculties and 15,505 students (Potkonjak, 1989).

World War II was a serious critical juncture (as it is considered in the historical institutionalism theory, Hall and Taylor, 1996). Following the war, the new institutional framework was established, with significant implications for the higher education system.

According to this theoretical approach, institutions are stable and durable, but there is also room for changes. However, changes and policyrelated decisions depend on internal institutional factors that emerge during the formation of institutions or through institutional development. In historical institutionalism, this dependence is known as path dependence. According to this concept, all the important decisions and choices that were made in the early history of a policy determine and limit any possible choices in the future. In order to implement changes and influence path dependence, strong political pressure is needed (Peters, 2005). Such periods of long-term continuity are interrupted by critical junctures, moments of substantial institutional changes (Hall and Taylor, 1996). They also define institutions as 'formal and informal procedures, routines, norms and conventions embedded in the organizational structure of the political system or political economy' (1996: 938).

The main question that the authors of this approach are trying to answer is why certain choices are made, why certain outcomes appear, and how institutions shape the behavior of individuals. Since the focus is on historical development, it should be noted that there are certain variables. Moreover, important variables often influence each other, and therefore it is impossible to apply the methods that are used in other approaches. Process tracing is the research method used in order to take into account the context, the historical development and a large number of variables. The results are displayed with detailed descriptions based on the research, while the inductive logic of inference is used. Studies based on the historical institutionalism approach focus on one or a small number of cases. The authors also strive to increase the number of cases in time, in order to compare different results and explain the logic of causality (Steinmo 2008, Sanders, 2006).

In this line, as Somolovčev (1989) claims, the next two periods in higher education development were characterized by ideological transformation and significant 
expansion. Šoljan (1991) also points out that there are two important features of post-war higher education development. First of all, university facilities were destroyed and reconstruction was required. The teaching staff was seriously diminished during the warfare, or was ideologically discredited. Secondly, the post-war period was characterized by reforms in education, the setup of new institutions, and a growing number of students. The positive trends of institutions and students were obvious on the short run - in 1948/49, there were 27 faculties within the above-mentioned universities, whereas in 1951/52 the students' number was as high as 53,584. In the period between 1957 and 1979, fourteen new universities were set up. Furthermore, Reichard (1992) claims that in 1970, higher education attendance was 641 per cent higher than in 1939. With this in mind, it would be possible to claim that the significant development of higher education in Yugoslavia occurred after World War II, through the reconstruction of the existing capacities, and the expansion of the higher education system.

\section{Specific Characteristics}

There were specific institutional characteristics of the higher education system in the Socialist Federalist Republic of Yugoslavia which can be considered important factors that could account for the problems facing the system. Non-integrated universities, the dissolution of the federal ministry of education, and the introduction of self-managed communities of interest are among such features.

\section{Non-integrated universities}

The faculties from the Universities of Zagreb and Belgrade 'are created after the traditional Central European pattern' (Šoljan, 1991:134), and a variety of disciplines are represented within one faculty. Formally, the faculties were part of the higher education institution (university), but they were actually independent and self-governed bodies. As the same author points out, universities lacked firm organizational or curricular connections. They can be described as 'compulsory associations of Faculties and Colleges (Samolovčev, 1989:31). Mandić (1992) describes the university as a free association of faculties and institutes. According to this author, the condition was to have at least three faculties and research institutes in order to set up a university, and the organization of teaching activities, enrolment, exams and students' problems were the task of individual faculties.

Furthermore, according to Marentič-Požarnik, Lapajne and Mihevc 1989:63:

Higher education institutions are self-governing units of a university. A faculty, for example, can consist of more of such institutions. Each of them has a council to manage its affairs [...] The University is more or less a loose association of faculties and other institutions. It coordinates admission procedures, common core curricula and the international contacts of its members; it issues diplomas, certificates and awards to outstanding students. 
This is also clear if we take into account the organization of a university and of its comprising faculties. Each faculty has its own council, the dean, vice-deans, a scientific committee, a textbook committee, a committee dealing with students' petitions and complaints, and a library. On the other hand, the university has its own bodies - the general assembly of the university (which includes the entire teaching staff from the faculties, and which elects the rector and the vicerectors), the council of the university (the rector, the vice-rectors, the deans and the vice-deans; it deals with general aspects), the rector and the vice-rectors (elected from among the professors) (Uvalić, 1952). The power of the faculties, as Marentič-Požarnik, Lapajne and Mihevc (1989) claim, was visible from the republican and provincial laws which only regulated general goals and functions for higher education, while the rest was left to the individual faculties. He considers that universities should have had more authority on these matters.

There is another issue which points to the non-integrated organization of universities. The analysis of the geographical location of university facilities (the faculties from the University of Zagreb and the University of Belgrade) reveals that they are dispersed around these two cities, and that there is no organization of a university as a campus. This form of allocation of facilities confirms the heterogeneity and non-integrated organization of the University of Zagreb and the University of Belgrade.

In 1980, at its peak, the Yugoslav higher education system included 228 faculties and art academies, and around
300,000 students (another 100,000 in High and 'Superior' schools) (Mandić, 1992). Since the universities were only loose associations of faculties and other institutions, they represented a complex higher education system with numerous autonomous institutions. The role of the university was reduced to minimal coordinating functions. Clearly, the role of the universities from the SFRY was purely administrative, and a university consisted of faculties which held most of the decision-making powers and acted as autonomous institutions.

\section{Dissolution of Federal Institutions for education and the introduction of self-management}

The reforms in the education system, which started after World War II, had a great impact on the position of universities. The 1958 educational reform started with the decentralization and debureaucratization. The most obvious changes in the higher education system were apparent under the form of new faculties. According to Potkonjak (1989), a number of new faculties were departments or programs of already existing faculties, which split and became autonomous after the reform. Next, at the beginning of 1960s, the changes in the Constitution introduced the idea of socialist self-government. Furthermore, the constituent Republics became more independent in their internal affairs, and were given greater responsibility for their own development. Their independence in higher education was even greater after the 1974 Constitution, when they were granted full educational 
autonomy, and the education body at Federal level was dissolved. The new Constitution was an important document for the further development of higher education. However, besides the Constitution, two equally important documents were also introduced - the Resolution on the Self-Managing Socialist Transformation of Education from 1974, and the Associated Labor Act from 1976. (Potkonjak, 1989)

These documents led to serious institutional changes specific to the SFRY. The former specific feature, which has already been mentioned before, was the absence of an educational body at Federal level. The latter was the introduction of self-managed communities of interest. I consider these two institutional novelties as enhancing forces in the process of weakening the position of universities in the higher education system.

\section{Self-managed communities of interest}

\section{The Idea}

The idea of self-management represented a new decision-making system in which decisions were made jointly by the all interested workers and citizens organized within interest communities, and it was an attempt of decision-making democratization (introduction of socialist democracy). One important factor was associated labor, which represents the power of the working class over the means of production, and their right to make decisions regarding social reproduction. In the case of higher education, decisions were made by the education institutions, as providers, and self-management communities of interest, as users of the service. Šljan claims that this new system:

means that the functions related to the policy and practice of higher education should pass from the State into the hands and competence of the workers and citizens associated into organizations of material and non-material production as well as into the hands of broader selfmanaging associations (1988:112)

or

in simpler language this means that the self-managing communities of interest are places where workers from direct production deal with workers from the 'social sphere' in order to satisfy a part of their needs and interest in the fields of education, science, culture, health and social welfare, etc. (1988:14).

In such organizations, higher education representatives, workers and citizens were supposed to debate and make decisions on long, medium and annual plans. The plans were drafted by higher education institutions, and included funding sources, expenses, number of students, educational activities, etc., aspects which were afterwards negotiated among the interested parties.

\section{The Reality}

However, in reality this system proved to be slow, inefficient, expensive, time-consuming and complicated. As Marentič-Požarnik, Lapajne and 
Miheve (1989) show, there were up to 5,500 different communities of interest in Yugoslavia (in the overall system), and in the higher education system numerous personnel members were needed in order to represent universities and faculties in different communities. The users' lack of interest and competence led to uninspired and questionable decisions. Furthermore, this process also impacted the authority exerted by universities. Their role was diminished, and their influence in the self-managing process was weakened. On the other hand, the influence of the communities of interest, the associated workforce and bureaucracy was higher than before. Higher education planning was carried out by the Party, trade unions, self-management bodies, youth organizations, etc. (Šoljan, 1991).

Moreover, the attempt of the State to grant the control over the decisionmaking process into the hands of workers and citizens did not prove to be functional from yet another reason. The State did not actually give up total control over the decisionmaking process. In the 1960s, at the very beginning of the democratization process, Milovan Djilas, one of the members of the Party elite, revealed that the democratic councils were under the control of the Party, the secret police and the army (Reichard, 1992). The power of these actors did not diminish after the introduction of self-management communities, and self-management was applied more in theory rather than in practice. The pressure exerted by political structures was permanent, and their influence was decisive in the decision-making process. The most obvious cases of the decisive role of the State were the 1968 student demonstrations, and the mass movement of students from Croatia in 1970 and 1971. In reply to these events, the State decided to cancel any financial subsidy for student journals, summer schools, while some professors were excluded from universities and some student leaders were imprisoned (Šoljan, 1989).

\section{Discussion and problems of unemployment and brain drain}

My conclusion regarding this attempt of democratization of the decisionmaking process is in line with the suggestions of the authors who researched this phenomenon at the time of its occurrence. The whole experiment was unsuccessful since it was consuming in terms of time and resources, it created numerous actors in the higher education system which were not competent and interested in this field, and finally, even though the State formally gave up its competencies, the real situation was that the State had no direct links with the higher education system, but it was still the main decision maker in this field.

This led to the situation in which large numbers of higher education institutions (faculties) were not considered in the negotiation process and had limited influence on final decisions. On the other hand, there were numerous institutions of selfmanaged communities with formally high influence and low competence in higher education matters. The universities had their role in this process of negotiation, but due to the institutional organization of the higher education system presented 
above, their role was negligible. Thus, instead of the economic planning system in which the State (or federal higher education institutions) would be responsible for planning together or in negotiation with the universities, the higher education system in the SFRY was organized in such a way that numerous actors on both sides were included in the decision-making process in which universities did not hold an important role and federal higher education institutions were abolished. The specific situation of the universities was noticed by Šoljan (1988:115) in his analysis of the 1974 reform, when he noted that 'recent experience also indicates that the traditional university - as a centralized organization which deals with the State as an independent partner - is beginning to disappear'. Regarding Šoljan's position, it is important to point out that the traditional position of the university from Yugoslavia never actually existed since it was only a loose organization of faculties. On the other hand, the State, which proclaimed its withdrawal from these matters, was the main decision-maker even though it was not in direct contact with higher education institutions.

The previously discussed problem of academic autonomy is recognized by Uvalić-Trumbić (1991). She claims that in order to reach appropriate autonomy it is necessary to reject all intermediaries that existed previously in decision-making process between the highest authority of the federal stages (the Assembly of Republics) and the university itself, such as: the Communist Party, the Socialist Alliance, the Youth Union, the 'selfmanaged communities of interest', etc. (1991: 403).
She also recognized the need for integration with the University as the prerequisite for the further development of higher education.

There were different consequences of this complex and inefficient institutional framework of the higher education system. First of all, the growing number of institutions and significant enrolment in higher education created an overflow of educated people in the SFRY. One of the goals of higher education in Yugoslavia was education for selfmanagement purposes (Potkonjak, 1989). Šoljan (1988) considers this self-managing opportunity the source of the new education needs and higher education as the cultural level of the entire community. Higher education was supposed to become the standard, the same as elementary and secondary education. Šoljan points out that one should know how to participate in selfmanagement, and not just have the opportunity to participate (1988). Thus, the idea of self-management required a further increase in enrolment quotas, since higher education was necessary for anyone who wanted to perform within these communities. However, since the community decision-makers incompetent, they were not able to recognize and anticipate the needs of the society, which impacted the overflow of graduates. The largest number of graduates was in the humanities sector, and fewer in natural and technical sciences, even though the latter were more needed as workforce. Šoljan noticed that

the expansion of higher education in some parts of the country has already created a discrepancy between the needs of associated 
labor and the professional profiles of the students supplied by the university. While some occupation skills are still in short supply, many university graduates cannot find work, and unemployment may well become a source of social tension (1988: 109).

Šoljan's prediction was correct; this situation led to a high number of unemployed graduates - in 1986 there were 58,847 unemployed graduates out of the total 1,086,600 unemployed (Uvalić-Trumbić, 1991, Šoljan, 1991).

Secondly, since graduates were not able to find a job in Yugoslavia, or were employed for positions which did not match their formal education, the brain drain process occurred. According to the estimate provided by Šoljan (1991), at the end of the 1980s, around 6,000 scientists and scholars and around 50,000 university graduates left Yugoslavia in 25 years. The little importance granted to science in Yugoslavia led to a colonial position of the country as compared to developed industrial states (Cifrić, 1989). If we take into account the number of unemployed graduates and of those who left the country, it appears obvious that more than 100,000 graduates were unable to find a job in Yugoslavia. According to Potkonjak (1989), between 1950 and 1985, there were around 1,000,000 graduates from higher education institutions. Thus, around one tenth of the graduates represented a surplus and the product of inefficient economic planning organized around self-management communities and the numerous faculties.

\section{The situation after the dissolution of the SFRY}

Surely, it is impossible to claim that the organization of the higher education system and non-integrated universities are the only factor responsible for the high number of unemployed graduates and brain drain. The economic crisis and the political situation prevailing in Yugoslavia were also important factors that cannot be neglected. However, the specific organization of higher education had its contribution. After the dissolution of Yugoslavia, the organization of the University of Zagreb and the University of Belgrade remained unchanged, and the problems regarding graduates' unemployment and brain drain were still a fact.

The dissolution of Yugoslavia did not represent the same critical turn point as had happened after World War II. The higher education system had a long continuity during socialism, and it was considerably developed. Moreover, there was no need for reconstruction, since there were no significant losses in terms of the teaching staff and facilities. Thus, universities continued to function in the same organizational environment, and the main change was the transition from socialism and economic planning to democracy and market economy.

The organization of both universities still follows the pattern of loose organization of faculties. According to Vujačić et al. (2013:22), the University of Beograd is still a 'weakly connected confederation of independent faculties', but there is a demand for the integration of the University. In addition, the university 
management is responsible only for unimportant tasks, and the higher education system is largely controlled by the State. The similar situation applies to the University of Zagreb. In Croatia there were certain attempts to achieve the integration of universities, but the traditional universities (those founded before the dissolution of Yugoslavia, including the University of Zagreb) remained non-integrated (Šćukanec, 2013). Lack of integration and the autonomy of faculties is obvious if take into account the Statute of the University of Zagreb ${ }^{2}$. It states that the faculties are legal entities with their own autonomy, they are owners of movable and immovable property, the teaching staff is employed by the faculties and not by the university, the faculties only need positive approval from the university regarding candidates running for dean, who is elected at each faculty, etc. Since historical institutionalism considers formal and informal procedures, routines, norms and conventions as equally important, it is worth mentioning that there are also certain informal relations which support this assumption. Thus, there are cases of duplicated curricula (such as psychology, sociology, history, etc.), duplicated departments and problems with holding courses at different faculties (internal mobility) within the same university.

Furthermore, the problems related to graduates' unemployment and braindrain are still unsolved. According to World Economic Forum reports, Serbia and Croatia were ranked low on the brain drain indicator. As shown in Table 1, these two countries scored extremely low, and the score diminished further still during the last several years; at present, they are among countries with the lowest performance in this area.

Table 1. The ranking of Serbia and Croatia on the brain drain indicator

\begin{tabular}{|c|c|c|c|c|c|c|}
\hline \multirow{2}{*}{ Year } & \multicolumn{2}{|c|}{ Serbia } & \multicolumn{2}{c|}{ Croatia } & \multirow{2}{*}{$\begin{array}{c}\text { No. of } \\
\text { countries }\end{array}$} & Worst score \\
\cline { 2 - 5 } & Rank & Score & Rank & Score & & \\
\hline $2007-2008$ & 131 & 1.9 & 75 & 3.1 & 134 & 1.6 \\
\hline $2008-2009$ & 132 & 1.9 & 98 & 2.8 & 133 & 1.9 \\
\hline $2009-2010$ & 136 & 2.0 & 122 & 2.3 & 139 & 2.0 \\
\hline $2010-2011$ & 139 & 1.8 & 128 & 2.2 & 142 & 1.7 \\
\hline $2011-2012$ & 141 & 1.9 & 126 & 2.4 & 144 & 1.5 \\
\hline $2012-2013$ & 146 & 1.8 & 134 & 2.3 & 148 & 1.7 \\
\hline
\end{tabular}

Source: World Economic Forum - The Global Competitiveness Report (2009, 2010, 2011, 2012, 2013, 2014) ${ }^{3}$

Also, as Vujačić et al. (2013) point out, the universities do not meet the needs of market and do not keep track of graduates' employability. In December, 2013 in Serbia there were 105,140 unemployed higher education graduates out of the total number of 796,546 unemployed, while in the Belgrade area there were 30,950 unemployed higher education graduates out of 108,706 . This means that there were around 30 per cent of unemployed higher education graduates in the Belgrade area 
(National Employment Service, 2013). In Croatia, according to the Croatian Statistics Bureau (2013), in 2013 there were around 11 per cent of unemployed higher education graduates; according to the Croatian Employment Service ${ }^{4}$ there were around 22,000 unemployed graduates (around 6,000 only in Zagreb), while between 1991 and 2001 almost 10,000 graduates left Croatia (Adamović and Mežnarić, 2003).

Since there is no coordination within the university and there is no interest in following the market needs, the university output is completely unadjusted with the employers current needs. This trend is obvious in the quotas of the University of Zagreb for the 2013/14 academic year: Humanities and Social Sciences - 6,393 students, Natural and Technical Sciences - 4,982 students, Biomedicine and Health 745 students, and Art - 276 students $^{5}$. The highest quota is represented by humanities and social sciences, even though these graduates face the greatest challenges being employed.

Even after the change of the political system and the transition from economic planning to market economy, the position of the university did not change. The contact with the labor market is weak, and the decisionmaking process is still in the hands of the State and the numerous faculties, whose goal is to maintain their power and increase profit. This institutional framework is the heritage of the previous system which has proven to be dysfunctional. However, this institutional organization is deeply rooted in the past, and the actors do not have any interest or power to change it. Moreover, there are no critical turnpoints that would enable a significant change of the system.

\section{Potential solutions}

The first solution would be to maintain the current organization of the universities. This is probably the solution that would benefit from the greatest support from faculties and their employees. Each faculty has its own administration and staff, that would decrease in number if universities were integrated. However, the preservation of the status quo would not solve the longstanding problems.

The second solution would be the introduction of integrated universities as in other European countries and worldwide. This would require great efforts from the responsible ministries and university structures, and the consent of all the faculties which would lose part of their autonomy. It would also be necessary to make great investments in campus infrastructure in order to eliminate the geographic dispersion of the facilities. The university management would be able to decide on the quotas for all the faculties (or departments, after the reform). Thus, it would have more control over planning, and greater openness to the requests of the market and of the State.

The third solution would entail the complete dissolution of current universities and the establishment of new universities (up to four) Humanities and Social Sciences, Natural and Technical sciences, Biomedicine and Health, and Art. This would reduce the number of actors, and would provide conditions for deeper cooperation in specific fields. A new 
institutional environment would create recognizable actors, which would be able to cooperate with the State and the market in order to satisfy their needs and provide better quality for their students.

\section{Notes}

1 The last one refers to the period between 1982 and 1989.

${ }^{2}$ More information available on the official web page of the University of Zagreb: http://www.unizg.hr/fileadmin/ rektorat/O_Sveucilistu/Dokumenti_ javnost/Propisi/statut.pdf
${ }^{3}$ The survey is conducted by Partner Institutes that administer the Executive Opinion Survey at national level (economics departments of national universities, independent research institutes, or business organizations). The question for the Brain drain ranking was: Your country's talented people $(1=$ normally leave to pursue opportunities in other countries, $7=$ almost always remain in the country).

${ }^{4}$ More info available on official web page of the Croatian Employment Service: http://statistika.hzz.hr/

${ }^{5}$ More info available on official web page of the University of Zagreb: http://www. unizg.hr/homepage/about-university/

\section{References}

Adamović, M. and S. Mežnarić (2003) 'Potencijalni i stvarni 'odljev’ znanstvenog podmlatka iz Hrvatske: emprijsko istraživanje'. Revija za sociologiju, 34(3-4): 143-160.

Cifrić, I. (1989) 'Professional Vacillation, or the Exodus of Young Scientists and Scholars' In Šoljan, N. (ed.) Higher Education in Yugoslavia, pp. 103-115. Zagreb: Andragogical Centre.

Croatian Bureau of Statistics (2013) Statistical Yearbook of the Republic of Croatia. Zagreb: Croatian Bureau of Statistics.

Hall, P.A. and C.R. Taylor (1996) 'Political Science and the Three New Institutionalisms'. Political Studies, (44)5: 936-957.

Mandić, P. D. (1992) 'Yugoslavia' in Clark, B.R. and Neave, G. (eds.) The Encyclopedia of Higher Education (Vol. 1: National Systems of Higher Education), pp. 811-820. Oxford: Pergamon Press.

Maretić-Požarnik, B., Lapajne, Z. and B. Mihevc (1989) 'Higher Education in Yugoslavia: Present Situation, Policy and New Tendencies' In Šoljan, N. (ed.) Higher Education in Yugoslavia, pp. 57-69. Zagreb: Andragogical Centre.

National Employment Service (2013) Monthly Statistic Bulletin December 2013. Unemployment and Employment in the Republic of Serbia. No.136. Belgrade: National Employment Service.

Peters, B. G. (2005) Institutional theory in political science. London: Continuum Potkonjak, N. (1989) 'Educational reforms in Yugoslavia and changes in Higher Education' In Šoljan, N. (ed.) Higher Education in Yugoslavia, pp. 45-57. Zagreb: Andragogical Centre.

Reichard, M. (1992) 'Politics and Culture in Croatian Higher Education: A 
Comparative Perspective on Educational Reform'. Community Services Catalyst, 22(4): 11-21.

Samolovčev, B. (1989) 'Higher Education in Yugoslavia: A Historical Overview' In Šoljan, N. (ed.) Higher Education in Yugoslavia, pp. 13-45. Zagreb: Andragogical Centre.

Sanders, E. (2006) 'Historical institutionalism' In Rhodes, R.A.W, Binder, S.A. and B.A. Rockman (eds.) The Oxford handbook of political institutions, pp. 39-55. Oxford: Oxford University Press.

Steinmo, S. (2008), Historical institutionalism' In Della Porta, D. and M. Keating (eds.) Approaches and Methodologies in the Social Science: A pluralist perspective, pp. 118-138 Cambridge: Cambridge University Press.

Šćukanec, N. (2013) 'National Report on Higher Education and Research:

Croatia'.http://www.herdata.org/public/HE_and_Research_in_Croatia_FINAL.pdf (Accessed 10 September 2013).

Šoljan, N. (1988) Yugoslav Education Under Examination: Educational Reform, Policy and Theory: 1974-1988-2002. Zagreb: Institute for Educational Research University of Zagreb Faculty of Philosophy.

Šoljan, N. (1989) 'Student Political Activism in Yugoslavia: Between Power and Anemia’ In Šoljan, N. (ed.) Higher Education in Yugoslavia, pp. 115-143. Zagreb: Andragogical Centre.

Šoljan, N. (1991) 'The Saga of Higher Education in Yugoslavia: Beyond the Myths of a Self-Management Socialist Society'. Comparative and International Education Society, 35(1): 131-153.

Uvalić, R. (1952) 'The Organization of Higher Education in Yugoslavia. United Nations Educational, Scientific and Cultural Organization'.

http://unesdoc.unesco.org/images/0017/001790/179034eb.pdf (Accessed 8 September 2013).

Uvalić-Trumbić, S. (1991) 'New Trends in Higher Education in Yugoslavia?'. European Journal of Education, 25(4): 399-407.

Vujačić, I. et al. (2013) 'National Report on Higher Education and Research:

Serbia'.http://www.herdata.org/public/HE_and_Research_in_Serbia_FINAL.pdf (Accessed 10 September 2013).

World Econimc Forum (2009) The Global Competitiveness Report 2008-2009. http://www3.weforum.org/docs/WEF_GlobalCompetitivenessReport_2008-09.pdf (Accessed 10 January 2014)

World Econimc Forum (2010) The Global Competitiveness Report 2009-2010 http:/www3.weforum.org/docs/WEF_GlobalCompetitivenessReport_2009-10.pdf (Accessed 10 January 2014)

World Econimc Forum (2011) The Global Competitiveness Report 2010-2011 http:/www3.weforum.org/docs/WEF_GlobalCompetitivenessReport_2010-11.pdf (Accessed 10 January 2014)

World Econimc Forum (2012) The Global Competitiveness Report 2011-2012 http://www3.weforum.org/docs/WEF_GCR_Report_2011-12.pdf (Accessed 10 January 2014)

World Econimc Forum (2013) The Global Competitiveness Report 2012-2013 
http://www3.weforum.org/docs/WEF_GlobalCompetitivenessReport_2012-13.pdf (Accessed 10 January 2014)

World Econimc Forum (2014) The Global Competitiveness Report 2013-2014

http://www3.weforum.org/docs/WEF_GlobalCompetitivenessReport_2013-14.pdf (Accessed 10 January 2014) 